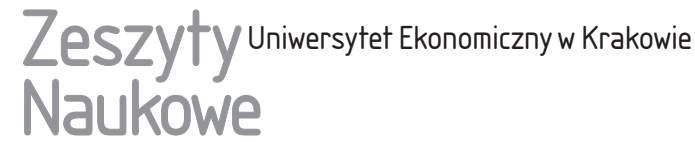

\section{Budżetowanie jako element planowania w przedsiębiorstwie}

\section{Streszczenie}

W artykule przedstawiono zasady planowania rzeczowo-finansowego w przedsiębiorstwie produkcyjnym. Zaprezentowano jedną z ważnych metod zarządzania przedsiębiorstwem, jaką jest budżetowanie. Budżetowanie obejmuje zespół różnych czynności wykonywanych zgodnie z zasadami i metodami właściwymi temu procesowi; czynności oznaczają również kwantyfikację opisowych zamierzeń i środków ich realizacji. Planowanie i kontrola działalności przedsiębiorstwa na podstawie budżetów jest koniecznością i jednym z podstawowych elementów prawidłowego zarządzania, plany rzeczowo-finansowe pozwalają w sposób zwarty i przejrzysty opisać zaplanowane potrzeby na nadchodzący okres oraz zestawić i zsumować ich koszty. W artykule analizie poddano dotychczasową praktykę w zakresie budżetowania, projektowania rachunków pro forma dotyczących realizacji procesów finansowania związanych z bieżącą działalnością przedsiębiorstwa oraz ze strategicznymi decyzjami finansowymi.

Słowa kluczowe: przedsiębiorstwo, finanse, budżetowanie, wskaźniki finansowe, sektor obronny.

Klasyfikacja JEL: L3, L22, P33, F37.

\section{Wprowadzenie}

Proces stałego doskonalenia systemu zarządzania przedsiębiorstwem wskazuje na szeroki zakres działań, które należy podjąć, aby osiągnąć poziom konkurencyj-

Renata Żaba-Nieroda, Uniwersytet Ekonomiczny w Krakowie, Wydział Finansów i Prawa, Katedra Polityki Przemysłowej i Ekologicznej, ul. Rakowicka 27,31-510 Kraków, e-mail: zabar@uek. krakow.pl 
ności pozwalający zająć silną pozycję na rynku. W literaturze przedmiotu i analizach badań empirycznych zaznacza się, że jedną z ważnych metod zarządzania przedsiębiorstwem jest budżetowanie. Jest to zespół różnych czynności wykonywanych zgodnie z zasadami i metodami właściwymi temu procesowi; czynności oznaczają również kwantyfikację opisowych zamierzeń i środków ich realizacji. Planowanie i kontrola działalności przedsiębiorstwa na podstawie budżetów jest koniecznością i jednym z podstawowych elementów prawidłowego zarządzania. Plany rzeczowo-finansowe pozwalają w sposób zwarty, zwięzły i przejrzysty opisać wszystkie brane pod uwagę potrzeby na nadchodzący okres planowania oraz zestawić i zsumować ich koszty. Celem artykułu jest przedstawienie roli budżetowania, szczególnie jako planowania rzeczowo-finansowego w przedsiębiorstwie produkcyjnym. Budżet - plan rzeczowo-finansowy, jest dokumentem planistycznym, przygotowanym w układzie miesięcznym, umożliwiającym planowanie działań w danym roku. Budżetowanie jest jednym z elementów prac przygotowawczo-rozwojowych. To proces planowania finansowego, na który składa się: budżetowanie kosztów przedsięwzięć, programowanie zmian, prognozowanie efektów, kontrola oraz analiza porównawcza. Budżetowanie to zespół działań, który pozwala w najbardziej efektywny sposób wykorzystać środki finansowe będące w dyspozycji firmy. Umożliwia także podejmowanie właściwych decyzji produkcyjnych i finansowych. Metodą badawczą wykorzystaną do potwierdzenia tezy postawionej w artykule jest analiza sprawozdań finansowych i sprawozdań rocznych zarządu badanego przedsiębiorstwa. Zadaniem zarządu jest koordynowanie różnych procesów, które zachodzą $\mathrm{w}$ firmie. $\mathrm{Z}$ procesami tymi związane są decyzje kierownicze, dotyczące takich obszarów, jak: produkcja, marketing, finanse i zaopatrzenie.

Koordynacja opiera się na sporządzaniu planów działania na najbliższy czas. Takie szczegółowe plany można określić mianem budżetów. Budżetowanie to proces prognozowania przyszłego stanu firmy, jej aktywów, kapitałów, kosztów i przychodów. Z kolei budżet to plan działania pokazujący sposób alokacji zasobów w formie wartościowej lub ilościowej, sporządzany na rok lub krótszy okres, zaakceptowany do realizacji, stworzony i realizowany przez pracowników różnych szczebli, kontrolowany i zmieniany.

\section{Specyfika i zadania przedsiębiorstw produkcyjnych}

Zarządzanie współczesnym przedsiębiorstwem jest procesem złożonym, wymaga posiadania i wykorzystywania wiedzy z różnych dziedzin życia gospodarczego. Na gruncie ekonomii nie udało się badaczom ustalić jednoznacznej definicji przedsiębiorstwa. Trudności wynikają z tego, że pojęcie to odzwierciedla 
złożone, wieloznaczne i wielopostaciowe zjawiska, które swoją naturę zmieniają wraz z dynamiką stosunków społeczno-gospodarczych, regulacji prawnych, jak również poziomem techniki (Podstawy... 2007, s. 68). Niejednorodność i niejednolitość interpretacji pojęcia przedsiębiorstwa uwarunkowana jest także różnym jego rozumieniem w różnych dyscyplinach naukowych, odmiennym ustrojem polityczno-gospodarczym kraju, a także intensywnie zachodzącymi zmianami wewnątrz i na zewnątrz przedsiębiorstwa (Godziszewski 2011, s. 24). Przedsiębiorstwo jest formą podejmowania i organizacji działalności gospodarczej. Działalność gospodarcza oznacza zarobkową aktywność wytwórczą, budowlaną, handlową, usługową oraz poszukiwanie, rozpoznawanie i wydobywanie kopalin ze złóż, a także działalność zawodową, wykonywaną w sposób zorganizowany i ciągły (Ustawa z dnia 2 lipca 2004 r....).

Przedsiębiorstwo to forma prowadzenia działalności gospodarczej przez przedsiębiorców (Famielec 2012, s. 19-23). W warunkach globalizacji gospodarki trudność sprawia definiowanie granic przedsiębiorstwa. Oczekiwania społeczeństwa dotyczące ochrony środowiska, zaangażowanie w działalność lokalnej społeczności i postępująca wirtualizacja przedsiębiorstwa mają wpływ na funkcje pełnione przez przedsiębiorstwo, co spowodowało sformułowanie wielu definicji, podejść i koncepcji teoretycznych przedsiębiorstwa. Sens przedsiębiorstwa wyrażają procesy produkcji, świadczenia usług, akceptowane przez rynek w postaci realizowanych i opłacanych transakcji kupna-sprzedaży (Famielec 2016, s. 60-74). W ramach prób ujmowania istoty przedsiębiorstwa przez konkretne dyscypliny nauk powstało wiele modeli, takich jak: model ekonomiczny, finansowy, produkcyjny, organizacyjny, prawny, behawioralny i etyczny (Podstawy... 2007, s. 68-69). Przedsiębiorstwo jest głównym subiektem gospodarki rynkowej. Kreuje podaż rynkową, jego działania zmierzają do osiągnięcia efektywności i skuteczności. Samo kreuje cel. Pokrywa koszty ze swoich dochodów i osiąga korzyści. Niezależnie wchodzi w kompromisy z innymi firmami i przedsiębiorstwami. Ponieważ działa w warunkach zmian koniunkturalnych, musi tworzyć swoją koncepcję rozwoju. Groźna staje się optymalizacja struktury produkcyjnej i organizacyjnej przedsiębiorstwa bez uwzględniania konsekwencji finansowych lub/i optymalizacji procesów finansowania bez uwzględniania zmian $\mathrm{w}$ otoczeniu, w technice, w technologiach (Famielec 2016, s. 60-74).

\section{Budżet zadań produkcyjnych}

Prowadzenie działalności gospodarczej wymaga wykorzystania środków produkcji, kadry, kapitału oraz informacji. Bardzo ważne jest umiejętne określenie zakresu i wielkości niezbędnych czynników produkcji oraz zapotrzebowania na 
związane z nim wydatki, w tym inwestycyjne, lokalowe i kadrowe (Famielec 2016, s. 69). Narzędzia rachunkowości zarządczej są stosowane przez menedżerów oraz zarząd w celu osiągnięcia korzyści ekonomicznych w postaci wyższego zysku. Poza rachunkiem kosztów często stosowanym i docenianym narzędziem jest budżetowanie, które wspomaga podejmowanie decyzji w różnych podmiotach gospodarczych. Budżetowanie to proces polegający na przygotowaniu, zatwierdzeniu, realizacji i kontroli budżetu (Szczypa 2008, s. 125). Budżet jest zestawieniem dwustronnym, ale liczby występujące w nim po stronie dochodów i po stronie wydatków, a więc ustalone w budżecie kwoty, mają charakter jedynie orientacyjny, są zestawieniem wielkości przewidywanych (Walczak i Kowalczyk 2010, s. 42). Inna definicja budżetowania opisuje je jako metodę wewnętrznego, oddolnego planowania w przedsiębiorstwie, podporządkowanego realizacji strategicznych celów i efektywnemu wykorzystaniu posiadanych zasobów (Komorowski 1997, s. 11). W przedsiębiorstwach produkcyjnych i usługowych tworzy się wiele tzw. budżetów cząstkowych, operacyjnych. Zestawienie ich wszystkich w jeden budżet oraz ich wykonywanie to proces budżetowania.

Prowadzenie działalności gospodarczej wymaga wykorzystania środków produkcji (środków pracy i przedmiotów pracy), kadry, kapitału oraz informacji. Przez produkcję rozumie się zespół skoordynowanych procesów pracy, w których świadoma i celowa działalność ludzka, czyli praca, przekształca przedmioty pracy w produkty (wyroby i usługi), używając do tego środków pracy (Pasternak 2005, s. 19).

Rachunkowość przedsiębiorstw produkcyjnych opiera się zarówno na przepisach prawa bilansowego, jak i na szczególnych rozwiązaniach uwzględniających specyfikę działalności i informacyjne potrzeby zarządzania jednostek gospodarczych. Podstawową częścią rachunkowości przedsiębiorstwa produkcyjnego jest rachunek kosztów normalnej działalności operacyjnej, którą ono prowadzi. W praktyce przydatność rachunku kosztów zależy od wielu czynników i różnych sytuacji, spośród których warto wymienić: sposób pomiaru i wyceny zużycia czynników produkcji, warianty ewidencji kosztów działalności produkcyjnej, metody rozliczania kosztów pośrednich i kalkulacji kosztów wytworzenia produktu (Rachunkowość przedsiębiorstw... 2014, s. 39).

Specyficzną działalność przedsiębiorstw produkcyjnych odzwierciedla przede wszystkim rachunek kosztów. Jest on podstawową częścią rachunkowości tych jednostek gospodarczych. Rachunek kosztów stanowi całościowy, uporządkowany układ metod, zasad i reguł postrzegania rzeczywistości (Jarugowa, Malec i Sawicki 1990, s. 52). W zależności od przyjętych przez jednostkę zasad w zakładowym planie kont, koszty normalnej działalności operacyjnej mogą być ewidencjonowane i/lub rozliczane w różny sposób. Rozróżnia się trzy warianty ewidencji kosztów (Rachunkowość przedsiębiorstw... 2014, s. 39): uproszczony, ujmujący 
wyłącznie koszty rodzajowe, ograniczony do kosztów według typu i funkcji działalności, rozwinięty, obejmujący zarówno koszty rodzajowe, jak i koszty według typu i funkcji działalności.

Controlling produkcji to element systemu controllingu przedsiębiorstwa. Wykorzystując różne instrumenty, wspiera on działania kierownictwa w zakresie planowania, realizacji i kontroli procesu produkcji, co pozwala na sprawne realizowanie przyjętych celów. Dla większych przedsiębiorstw produkcyjnych, szczególnie stosujących bardziej zaawansowane technologie, controlling produkcji jest ważnym narzędziem pozwalającym na utrzymywanie oraz poprawę pozycji konkurencyjnej (Nowak 2003, s. 138).

Controlling strategiczny nastawiony jest na długi, wręcz nieograniczony horyzont czasowy, dzięki czemu ma zapewnić przedsiębiorstwu przetrwanie oraz długotrwałe korzyści ekonomiczne. Podstawowym jego zadaniem jest wsparcie przy budowie kompleksowego i zintegrowanego systemu zarządzania produkcją oraz zapewnienie informacji potrzebnych kierownictwu do formułowania celów i podejmowania decyzji strategicznych (Controlling funkcyjny... 2004, s. 138). W obszarze produkcji podstawowe znaczenie mają długookresowe programy produkcji, niezbędne czynniki produkcji oraz stosowane technologie wytwarzania. Oprócz analizowania wnętrza firmy oraz monitorowania otoczenia, controlling powinien również wspierać wybór właściwej technologii z uwzględnieniem postępu technologicznego, potrzeb klientów, zmian w przedsiębiorstwach konkurencyjnych oraz skutków finansowych dla przedsiębiorstwa (Wnuk-Pel 2009, s. 284). Controlling operacyjny skupia się na kształtowaniu zysku w krótkich okresach. Controlling produkcji koncentruje się na tych elementach wyniku, które zależne są od decyzji podejmowanych w ramach zarządzania. Ważnym elementem redukcji kosztów, obok minimalizacji nakładów materiałów i skracania czasu wytwarzania, jest zwiększanie serii produkcyjnych i minimalizacja liczby przezbrojeń przy uwzględnieniu dodatkowych koszów magazynowania (Nowak 2014, s. 287). Kontrola procesu produkcyjnego sprowadza się do oceny wielkości produkcji w stosunku do założonych planów, terminowości, stopnia wykorzystania czynników produkcji (ilość odpadów, czas przestojów), kontroli kosztów (określenie kosztu jednostkowego produktu, kosztów przezbrojeń itd) oraz kontroli jakości, co ma prowadzić do minimalizacji liczby braków i reklamacji (Controlling funkcyjny... 2004, s. 139-144). Narzędzia controllingu operacyjnego produkcji opierają się głównie na rachunkowości zarządczej i są to m.in.: rachunek kosztów zmiennych, wielostopniowy rachunek marży brutto, budżetowanie zerowe, budżetowanie oparte na procesach, system wskaźników oceny sytuacji finansowej.

W firmach produkcyjnych wzrasta rola controllingu operacyjnego. Odgrywa on strategiczną rolę w procesie budżetowania, kontroli kosztów, planowania i monitorowania zmian poziomu kapitału pracującego, płynności firmy oraz aktywów 
i pasywów firmy. Podstawowym zadaniem komórki rachunkowości zarządczej, kierowanej przez głównego kontrolera kosztów, jest koordynowanie i konsolidowanie budżetów kosztów tworzonych w centrach kosztów produkcji podstawowej, pomocniczej oraz wydzielonych centrach kosztów nieprodukcyjnych. Proces budżetowania kosztów w podmiotach wewnętrznych koordynuje planista kosztów w porozumieniu z kierownikami centrów kosztów. W dużych przedsiębiorstwach, o skomplikowanym procesie produkcyjnym, w centrach kosztów powoływani są tzw. inżynierowie kosztów pełniący funkcje kontrolerów kosztów na poziomie zakładu, wydziału i oddziału. W centrach kosztów produkcji podstawowej i pomocniczej tworzone są budżety kosztów materiałów bezpośrednich, kosztów płac bezpośrednich oraz kosztów wydziałowych. W komórce rachunkowości zarządczej planista kosztów, na podstawie budżetów, tworzy operacyjne budżety kosztów podmiotów wewnętrznych produkcji podstawowej i pomocniczej oraz całościowy budżet kosztów produkcyjnych i nieprodukcyjnych. Budżety kosztów nieprodukcyjnych przygotowywane są w miejscach ich powstania.

Komórka rachunkowości zarządczej na podstawie danych księgowych przygotowuje dla kierowników centrów kosztów sprawozdania z wykonania budżetów kosztów produkcyjnych i nieprodukcyjnych. Zbiorcze zestawienia z wykonania tychże budżetów przygotowuje i analizuje analityk kosztów. On też przedstawia wnioski (Dura 2001, s. 50): głównemu kontrolerowi kosztów, kierownikowi działu controllingu, szefowi produkcji i dyrektorowi finansowemu.

Ocenę wykonania budżetów kosztów produkcyjnych i nieprodukcyjnych przeprowadza się co miesiąc. Ostateczne rozliczenie następuje jednak co kwartał (narastająco), po jego zakończeniu. W komórce rachunkowości zarządczej planista kosztów przygotowuje budżetowany koszt jednostkowy produktu, wykorzystując przygotowane wcześniej (Czubakowska 2004, s. 6): budżety kosztów pośrednich w centrach kosztów, normy zużycia materiałów bezpośrednich, normy pracochłonności oraz normy braków i ubytków.

Budżety kosztów pośrednich są podstawą do ustalania budżetowanych narzutów lub normatywnych stawek pośrednich. Za pomocą tych narzutów lub stawek oblicza się w kalkulacjach planowanych kosztów jednostkowych produktów budżetowane koszty pośrednie.

W ostatniej fazie procesu budżetowania kosztów komórka rachunkowości zarządczej w oparciu o przygotowany budżet kosztów, budżetowy koszt jednostkowy produktu oraz plan sprzedaży prognozuje wynik finansowy firmy na podstawie rachunku kosztów zmiennych i pełnych oraz szacuje próg rentowności. Bez wykorzystania obu systemów rachunku kosztów nie można ustalić wyniku finansowego na potrzeby sprawozdawczości zarówno zewnętrznej, jak i wewnętrznej. 
Analityk kosztów, dysponując planowanym i rzeczywistym wynikiem finansowym, może dokonać przyczynowej analizy odchyleń rzeczywistego wyniku finansowego od wyniku planowanego. Celem tego rodzaju analizy jest określenie wagi i wyjaśnienie przyczyn powstania różnego rodzaju odchyleń, a ponadto kontrola i ocena działania menedżerów odpowiedzialnych za funkcjonowanie przedsiębiorstwa. Planowanie i analiza progu rentowności, realizowane w komórce rachunkowości zarządczej, dostarczają informacji niezbędnych przy podejmowaniu decyzji o wielkości i strukturze produkcji, sprzedaży, a także danych do prognozowania wyników działalności przedsiębiorstwa w krótszym i dłuższym okresie. Próg rentowności może być wykorzystywany przy podejmowaniu decyzji związanych z rozmiarami planowanych inwestycji, w wyznaczaniu minimalnej skali produkcji i sprzedaży gwarantującej pokrycie poniesionych nakładów inwestycyjnych. Planowanie i analiza progu rentowności w krótkim okresie powinny obejmować planowanie przeciętnego, minimalnego i maksymalnego progu rentowności, dźwigni operacyjnej, finansowej i łącznej, analizę wrażliwości progu rentowności na zmiany warunków rynkowych oraz kosztów i dochodów przedsiębiorstwa.

Całość planów kosztowych i finansowych przedsiębiorstwa znajduje podsumowanie $\mathrm{w}$ formie planowanego sprawozdania z przepływu środków pieniężnych oraz planowego bilansu. Oba sprawozdania pro forma przygotowuje planista finansowy. Planowanie sprawozdania z przepływów środków pieniężnych $\mathrm{z}$ podziałem na okresy miesięczne jest przydatne do określania płynności przedsiębiorstwa. Sprawozdanie to dostarcza obrazu planowanych sald pieniężnych, a w konsekwencji umożliwia interwencję przedsiębiorstwa w razie wykrycia znacznych niedoborów czy nadwyżek. Ostatnim elementem systemu sprawozdań pro forma jest bilans pro forma. Punktem wyjścia do jego sporządzenia są bilans rzeczywisty na początek okresu, budżety kosztów, planowany wynik finansowy, planowane sprawozdanie z przepływu środków pieniężnych oraz dane dodatkowe dotyczące np. polityki inwestycyjnej przedsiębiorstwa. Plan bilansu na dzień kończący prognozę nie ma takiego znaczenia jak planowany rachunek wyników czy plan przepływu środków pieniężnych. Stanowi w głównej mierze swego rodzaju sprawozdanie, czy przyjęte w całym procesie planowania założenia w sposób kompleksowy i merytorycznie poprawny zostały uwzględnione.

Analiza podstawowych wskaźników finansowych to ostatni, najbardziej ogólny instrument kontroli w przedsiębiorstwie, realizowany przez komórkę kontrolera finansowego. Dla celów kontroli operacyjnej dział kontrolera finansowego powinien opracować własny, oryginalny system wskaźników, które najpełniej pozwolą kontrolować i analizować rezultaty działalności. System raportowania wewnętrznego w przedsiębiorstwie jest ściśle związany z jednej strony z funkcjami działu controllingu, a z drugiej strony z potrzebami informacyjnymi kadry. 


\section{Zasady opracowania planów rzeczowo-finansowych w badanej grupie kapitałowej}

W ramach nadzoru w badanej grupie kapitałowej prezentowane są wytyczne do opracowywania rocznych planów rzeczowo-finansowych oraz ich analiz. Roczne plany rzeczowo-finansowe $\mathrm{w}$ spółach zależnych powinny być przygotowywane według określonych wytycznych, a przedstawiciele właściciela w radach nadzorczych tych spółek są zobowiązani do ich stosowania. Stosowanie wytycznych ma na celu zapewnienie jednolitości systemu planowania celów gospodarczej działalności właściciela przez wyznaczanie przez radę nadzorczą każdej spółce wymiernych celów cząstkowych, spójnych z przyjętymi celami strategicznymi, a także stworzenie systemu planowania rocznych celów działalności gospodarczej każdej spółki oraz ustanowienie elementu systemu monitorowania i kontroli obowiązującego w spółkach zależnych. Budżet powinien zawierać wszystkie działania, które mają zostać wykonane w celu wprowadzenia w życie przyjętej strategii.

Tabela 1. Struktura rocznego budżetu

\begin{tabular}{|c|c|}
\hline \multicolumn{2}{|c|}{ Struktura rocznego planu rzeczowo-finansowego } \\
\hline 1. Wstęp & - \\
\hline 2. Dane ogólne o spółce & $\begin{array}{l}\text { 2.1. Nazwa i siedziba } \\
\text { 2.2. Struktura kapitału zakładowego } \\
\text { 2.3. Przedmiot działalności } \\
\text { 2.4. Struktura organizacyjna } \\
\text { 2.5. Organy spółki }\end{array}$ \\
\hline $\begin{array}{l}\text { 3. Założenia realizacji planu rzeczowo-finanso- } \\
\text { wego na rok obrotowy }\end{array}$ & $\begin{array}{l}\text { 3.1. Czynniki warunkujące realizację planu } \\
\text { na rok obrotowy } \\
\text { 3.2. Podstawowe założenia przyjęte przy } \\
\text { konstruowaniu planu }\end{array}$ \\
\hline 4. Plan marketingowy & $\begin{array}{l}\text { 4.1. Ocena aktualnej sytuacji marketingowej } \\
\text { 4.2. Cele marketingowe } \\
\text { 4.3. Strategie marketingowe i programy działań } \\
\text { 4.4. Budżet marketingowy } \\
\text { 4.5. Kontrola wyników }\end{array}$ \\
\hline 5. Plan techniczny & $\begin{array}{l}\text { 5.1. Opis produktów i przedsięwzięć } \\
\text { 5.2. Poziom technologii i organizacji } \\
\text { 5.3. Program produkcji } \\
\text { 5.4. Majątek produkcyjny } \\
\text { 5.5. Poziom zapasów wyrobów gotowych } \\
\text { 5.6. Zdolności produkcyjne i plan produkcji } \\
\text { 5.7. Koszty produkcji } \\
\text { 5.8. Zarządzanie procesami logistycznymi } \\
\text { 5.9. Działalność badawczo-rozwojowa }\end{array}$ \\
\hline
\end{tabular}


cd. tabeli 1

\begin{tabular}{|l|l|}
\hline \multicolumn{2}{|c|}{ Struktura rocznego planu rzeczowo-finansowego } \\
\hline 6. Przedsięwzięcia w zakresie zarządzania & 6.1. Przedsięwzięcia organizacyjne \\
spółką & 6.2. Polityka kadrowo-płacowa \\
& 6.3. Zarządzanie majątkiem spółki \\
& $\begin{array}{l}\text { 6.4. Organizacja kontroli wewnętrznej } \\
\text { w spółce }\end{array}$ \\
& $\begin{array}{l}\text { 6.5. Zarządzanie finansami spółki } \\
\text { 6.6. Controlling finansowy }\end{array}$ \\
& $\begin{array}{l}\text { 7.1. Prognoza rachunku zysków i strat } \\
\text { 7. Plan finansowy }\end{array}$ \\
& $\begin{array}{l}\text { 7.2. Prognoza bilansu } \\
\text { pieniężnych }\end{array}$ \\
& 7.4. Prognoza nakładów inwestycyjnych \\
& 7.5. Przewidywane zmiany w strukturze \\
& kapitałów własnych \\
8. Zagrożenia realizacji planu & 7.7. Pnaliza wrażliwości zysku \\
\hline 9. Podsumowanie & - \\
\hline
\end{tabular}

Źródło: opracowanie własne.

Roczny budżet służy do prezentacji zamierzeń i monitorowania stanu ekonomiczno-finansowego spółek. Jest podstawowym dokumentem dla zarządu, zawierającym cele i kierunki działań w danym roku obrotowym, planowane do wykonania konkretne zadania oraz przewidywane efekty, w tym w szczególności: udział w realizacji kontraktów, udział w przedsięwzięciach, opis projektów inwestycyjnych przewidzianych w danym roku, prognozy finansowe, a w przypadku planowanych inwestycji biznesplan dla danego przedsięwzięcia. W tabeli 1 przedstawiono strukturę rocznego planu rzeczowo-finansowego obowiązującego w spółkach badanej grupy.

\section{Prezentacja przedsiębiorstwa w planie rzeczowo-finansowym}

Europejski przemysł obronny jest światowym centrum produkcji i innowacji, tworzy nowe miejsca pracy i przyczynia się do wzrostu gospodarczego. W $2015 \mathrm{r}$. obroty unijnego przemysłu obronnego wyniosły 96 mld euro. Rozwój i utrzymanie technologii oraz krytycznych możliwości przemysłu obronnego pozostają poza możliwościami pojedynczych państw członkowskich. Istotny wpływ na pozycję rynkową polskiego przemysłowego potencjału obronnego ma proces przekształceń strukturalnych sektora. 
W kontekście rozwoju przemysłowego potencjału obronnego istotnym zagadnieniem jest transfer innowacyjnych technologii między sektorem wojskowym a sektorem cywilnym. Konieczne jest większe wykorzystanie potencjału rozwojowego tkwiącego w tym przepływie, a zwłaszcza podjęcie działań stymulujących przepływ wiedzy oraz zasobów ludzkich i sprzętowych z sektora wojskowego do cywilnego. Efektywne wspieranie rozwoju sektora przemysłu obronnego jest prowadzone przez utworzenie skonsolidowanej struktury polskiego przemysłowego potencjału obronnego oraz wzmocnienie wspomagających ją mechanizmów i instrumentów finansowych. Konsolidacja sektora obronnego oznacza wykorzystanie potencjału polskich zakładów zbrojeniowych oraz wzmocnienie ich konkurencyjności. Skupione w PGZ SA spółki mogą wspólnie realizować zamówienia Ministerstwa Obrony Narodowej (MON), mogą się wspierać, razem tworzyć marketing i wymieniać się technologiami. Skonsolidowana grupa posiada kapitał o wartości 6 mld zł i zatrudnia 14 tys. pracowników. Łączne przychody grupy to 5 mld zł rocznie. PGZ SA konsoliduje ponad 30 spółek (z branży zbrojeniowej, stoczniowej, offshore i nowych technologii). Konsolidacja zapewnia zwiększenie nakładów na prace badawczo-rozwojowe związane z bezpieczeństwem i obronnością państwa, skonsolidowanie zaplecza badawczo-rozwojowego oraz efektywniejsze wsparcie i promocję sektora. Na rys. 1 przedstawiono schemat konsolidacji PGZ SA.

Badane przedsiębiorstwo wchodzi w skład PGZ SA i ma szczególne znaczenie gospodarczo-obronne (Rozporządzenie Rady Ministrów z dnia 4 października 2010 r. ...). Status prawny przedsiębiorstwa to spółka akcyjna. Wśród grup wyrobów oraz usług świadczonych przez spółkę znajdują się: badania naukowe i prace rozwojowe, projektowanie specjalistyczne, karabiny maszynowe i wielolufowe karabiny maszynowe, karabiny wyborowe, granatniki jednostrzałowe i rewolwerowe, przeciwlotnicze zestawy artyleryjsko rakietowe holowane i samobieżne, moździerze, zdalnie sterowane moduły uzbrojenia, podkadłubowe stanowiska uzbrojenia śmigłowców, modułowe mobilne kontenerowe systemy ochronno-obronne, modułowe kontenerowe systemy szkolenia strzeleckiego, obróbka cieplna, galwaniczna i plastyczna, odsprzedaż energii elektrycznej. Analizowane przedsiębiorstwo działa na podstawie: kodeksu spółek handlowych (Ustawa z dnia 15 września 2000 r....), ustawy o komercjalizacji i prywatyzacji przedsiębiorstw państwowych (Ustawa z dnia 30 sierpnia 1996 r....) oraz statutu spółki. Spółka posiada szeroki i zróżnicowany portfel produktów i usług, na których konkurencyjność wpływa m.in. fakt, że wszystkie produkowane wyroby znajdujące się w wyposażeniu sił zbrojnych i stanowią ważny element uzbrojenia polskiej armii. Oferta obejmuje kompleksowe zaspokojenie wymagań użytkownika, co zwiększa jej atrakcyjność. Głównym odbiorcą produktów spółki jest MON. Badana spółka charakteryzuje się stabilnym poziomem sprzedaży, od 


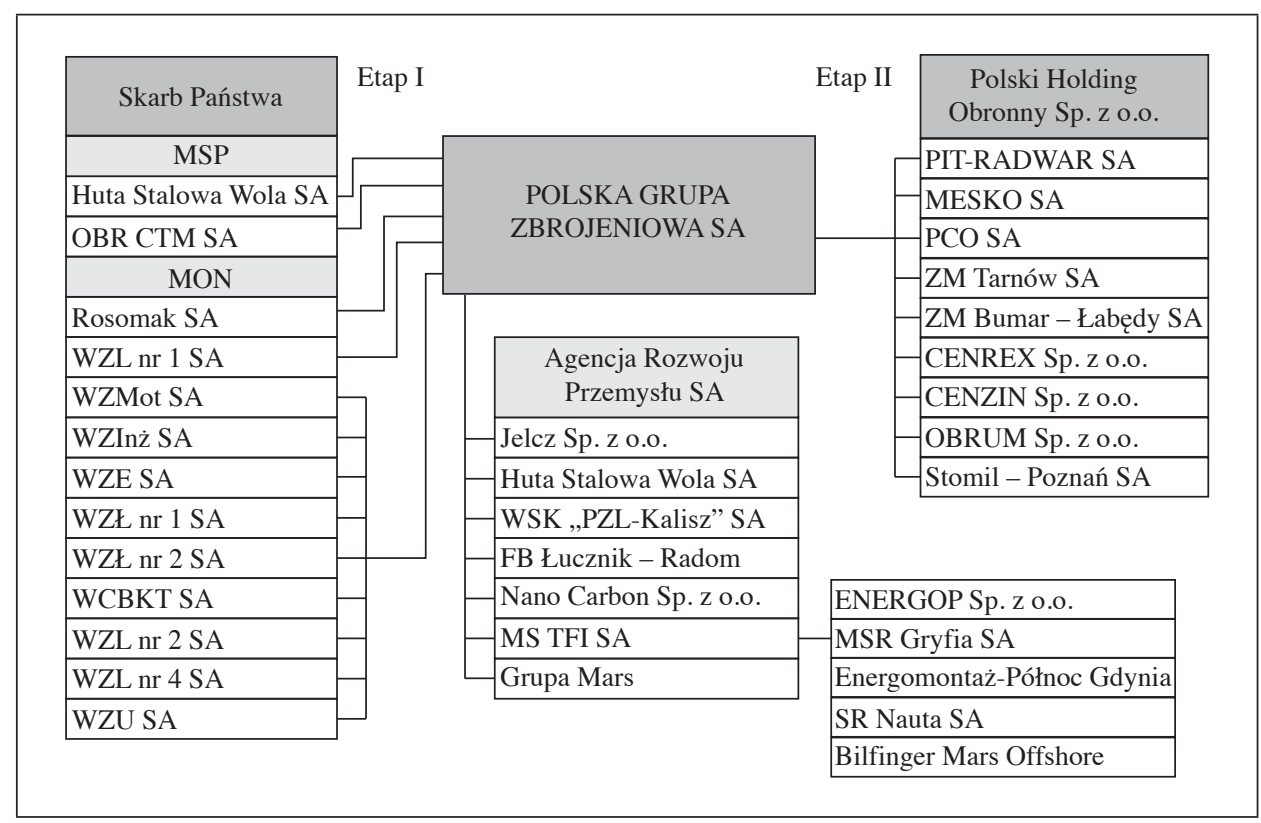

Rys. 1. Schemat konsolidacji PGZ SA

Źródło: opracowanie własne na podstawie danych uzyskanych w PGZ SA.

2018 r. planowany jest jej znaczny wzrost - o ponad 70\% w stosunku do $2016 \mathrm{r}$. ze względu na zapowiadany udział w realizacji programów modernizacyjnych sił zbrojnych w latach 2013-2022. Spółka jest liderem jednego z najważniejszych projektów, a do większości programów może oferować uzbrojenie i sprzęt wojskowy. W zakresie produkcji uzbrojenia i sprzętu wojskowego występuje w Polsce historyczna specjalizacja asortymentowa poszczególnych producentów, co stanowi zdecydowaną przewagę konkurencyjną spółki na polskim rynku.

\section{Plan produkcji i sprzedaży}

W badanym przedsiębiorstwie do zarządzania, w tym do planowania zadań produkcyjnych, wykorzystuje się informatyczny system wspomagania zarządzania przedsiębiorstwem klasy ERP, obejmujący wszystkie obszary działalności. Strategia marketingowa wynika z misji przedsiębiorstwa, a misja jest spójna z charakterem rynku docelowego, na który mają wpływ uwarunkowania polityczne i administracyjne oraz który regulują przepisy o obrocie uzbrojeniem i sprzętem wojskowym. Tej strategii podporządkowany jest rozwój potencjału badawczo-rozwojowego oraz 
unowocześnienie infrastruktury produkcyjnej. Strategia podstawowa okresowo wspierana jest strategią dywersyfikacji poziomej. Spółka, oprócz prowadzenia działalności w zakresie broni przeciwlotniczej i karabinów maszynowych, wprowadziła na rynek wyroby w nowych obszarach: karabinów wyborowych, zdalnie sterowanych modułów uzbrojenia, uzbrojenia lotniczego, systemów kontenerowych oraz karabinów skierowanych na rynek cywilny. Ze względu na ograniczoną wielkość rynku polskiego rozwój spółki może zapewnić eksport wyrobów. Ten obszar działalności podlega strategii rozwoju rynku.

Za stworzenie planu produkcji przedsiębiorstwa odpowiedzialny jest główny specjalista ds. planowania produkcji. Plan produkcji jest ściśle skorelowany z planem sprzedaży. W każdym przypadku podstawą uruchomienia produkcji jest zlecenie produkcyjne. Plan opracowywany jest na podstawie podpisanych umów handlowych, prowadzonych procesów. Planuje się realizację nowych wyrobów, takich jak: zmodyfikowany karabin, ręczny granatnik powtarzalny, karabin snajperski oraz zdalnie sterowany moduł uzbrojenia.

\section{Planowanie elementów sprawozdania finansowego}

Obszary działalności przedsiębiorstwa sprowadzone są w rachunkowości do działalności operacyjnej, inwestycyjnej i finansowej (Ustawa z dnia 29 sierpnia 1994 r....). Trwałą strukturę bilansową zapewnia stabilność podstawowej działalności gospodarczej przedsiębiorstwa. Przychody ze sprzedaży netto w badanej spółce kształtowały się w $2016 \mathrm{r}$. na poziomie $45 \mathrm{mln}$ zł. Inwestycje w aktywa trwałe spowodowały wzrost amortyzacji o $23 \%$ w stosunku do 2015 r. Pomimo spadku przychodów utrzymano dodatnią rentowność sprzedaży na poziomie 13,3\%. Badane przedsiębiorstwo w 2017 r. planowało wzrost sprzedaży wyrobów i usług do poziomu blisko $180 \mathrm{mln}$ zł. Zysk ze sprzedaży zaplanowano na poziomie $6 \mathrm{mln}$ zł. Zaplanowana wielkość sprzedaży pozwoliła wygenerować dodatnie wyniki finansowe na wszystkich poziomach sporządzanego rachunku wyników. W ramach działalności inwestycyjnej zaplanowano kontynuowanie budowy Centrum Badawczo-Rozwojowego, dzięki któremu wzmocnione zostaną kompetencje inżyniersko-techniczne, wytwórcze, gwarantujące wysoką jakość produktów oraz konkurencyjność na rynku zbrojeniowym. W ramach prac badawczo-rozwojowo-wdrożeniowych w 2017 r. zaplanowano kontynuację projektów dofinansowanych z MSP - łączny plan nakładów na te prace wyniósł blisko $64 \mathrm{mln}$ zł.

Ostatni etap budżetowania stanowi reakcja podmiotu na wyniki realizacji budżetu. W tej fazie kierownicy podejmują decyzje, co należy zmienić w przedsiębiorstwie i kolejnych budżetach, aby wyniki w przyszłości były zadowalające. 
Podejmują także działania korekcyjne w obszarach, w których powstały odchylenia stanu rzeczywistego od stanu postulowanego.

Bardzo ważna jest weryfikacja budżetów, tj. ich kontrola. W tej fazie budżetowania realizowane są podstawowe zadania, do których zaliczyć należy:

- ujawnienie odchyleń wielkości rzeczywistych lub przewidywanych od wielkości założonych w budżecie,

- identyfikacja miejsc powstawania odchyleń,

- rozpoznawanie przyczyn odchylén,

- ustalenie osób odpowiedzialnych za powstanie odchyleń w trybie ex post,

- badanie skutków powstawania odchyleń w różnych obszarach działalności przedsiębiorstwa,

- wskazywanie działań korygujących zaistniałe odchylenia,

- postulowanie czynności zaradczych eliminujących powstawanie odchyleń w przyszłości,

- proponowanie zmian w funkcjonowaniu przedsiębiorstwa,

- wnioskowanie konkretnych usprawnień w samym procesie budżetowania.

Można zauważyć, że dużą rolę w kontroli budżetów odgrywa analiza odchyleń. Aby można było jej dokonać, należy wyodrębnić odchylenia, które w znaczny sposób przekraczają poziom tolerancji, oraz te, których poziom mieści się w określonych granicach. Odchylenia istotne można podzielić na dwie grupy: kontrolowane i niekontrolowane. Odchylenia kontrolowane dzieli się z kolei na korzystne i niekorzystne. Kontrola budżetu przez analizę odchyleń sprawia, że przedsiębiorstwo nie dopuszcza do obniżenia poziomu własnej płynności finansowej. Jest to swego rodzaju system wczesnego ostrzegania: jeżeli odchylenia są na tyle duże, że mogą zagrozić płynności, kadra zarządzająca natychmiast stosuje środki naprawcze. Nie wolno dopuścić do utraty kontrahentów i wiarygodności jednostki. Odchylenia w zużyciu zapasów powodują wzrost kosztów przedsiębiorstwa, odchylenia w terminowości spłaty należności - utratę płynności, niezrealizowanie planowanej wielkości sprzedaży - zmniejszenie przychodów. Wszystkie te wielkości mają wpływ na osłabienie kondycji finansowej przedsiębiorstwa, lecz wykryte w odpowiednim czasie i korygowane przez działania naprawcze nie spowodują utraty płynności czy bankructwa. W tabeli 2 zaprezentowano wskaźniki ekonomiczne, które opracowano na podstawie wytycznych do sporządzania rocznych planów rzeczowo-finansowych w badanej grupie kapitałowej.

Na 2017 r. zaplanowano wskaźnik rentowności obrotu przychodów na poziomie $3,7 \%$, rentowność majątku na poziomie $2,6 \%$, a rentowność kapitałów własnych na poziomie $5,5 \%$. W kolejnych latach po zakończeniu realizowanych projektów inwestycyjnych oraz wdrożeniu do produkcji realizowanych prac badawczo-rozwojowych rentowność spółki będzie systematycznie wzrastać. Spółka będzie osiągać wyższe wskaźniki rentowności dzięki prowadzonym aktualnie działaniom. 
Tabela 2. Wartość wskaźników ekonomicznych ujęta w planach badanej spółki na 2017 r.

\begin{tabular}{|l|c|}
\hline \multicolumn{1}{|c|}{ Wskaźnik } & Plan na 2017 r. \\
\hline Rentowność obrotu netto (w \%) & 3,7 \\
\hline Rentowność majątku ogółem (w \%) & 2,6 \\
\hline Rentowność kapitałów własnych (w \%) & 5,5 \\
\hline Rentowność sprzedaży (w \%) & 15,2 \\
\hline Wskaźnik poziomu kosztów (w \%) & 95,4 \\
\hline Wydajność pracy na 1 zatrudnionego (w tys. zł.) & 191,8 \\
\hline Wskaźnik płynności I stopnia & 0,06 \\
\hline Wskaźnik płynności II stopnia & 1,29 \\
\hline Wskaźnik płynności III stopnia & 1,99 \\
\hline Wskaźnik obrotu zapasami (w dniach) & 103,7 \\
\hline Wskaźnik obrotu należnościami (w dniach) & 29,19 \\
\hline Wskaźnik obrotu zobowiązaniami (w dniach) & 188,1 \\
\hline Ogólny poziom zadłużenia (w \%) & 56,1 \\
\hline
\end{tabular}

Źródło: opracowanie własne.

Zastosowana metodologia liczenia wskaźników pozwala na utrzymanie bezpiecznego poziomu płynności finansowej. W planach na 2017 r. określono, że wskaźnik płynności I stopnia wyniesie 0,06, wskaźnik płynności II stopnia - 1,29, a wskaźnik płynności III stopnia - 1,99. Wskaźnik zadłużenia spółki zaplanowano na poziomie $56,1 \%$ i wynika to głównie ze zobowiązań związanych z finansowaniem działań inwestycyjnych. Zaplanowano skrócenie cyklu obrotu zapasów oraz cyklu należności, co skutecznie poprawi płynność finansową.

Siła finansowa przedsiębiorstwa wyraża zdolność wykorzystania części przychodów ze sprzedaży w postaci nadwyżki pieniężnej. Wskaźniki finansowe są przydatne w diagnozie sytuacji i wyborze strategii zmian struktury finansowania oraz w ocenie potencjalnych skutków stosownych instrumentów tych zmian.

\section{Zakończenie}

Na podstawie przeprowadzonej analizy dotyczącej planowania rzeczowo-finansowego w przedsiębiorstwie sformułować można następujące wnioski: plany rzeczowo-finansowe są narzędziem wspomagającym zarządzanie przedsiębiorstwem oraz narzędziem komunikacji z interesariuszami. W opracowaniu przedstawiono plan rzeczowo-finansowy w przedsiębiorstwie produkcyjnym jako dokument istotny w codziennym funkcjonowaniu spółki. Dobry, realny plan pozwala zaplanować w przyszłości określone działania. Narzędzia rachunko- 
wości zarządczej są stosowane przez menedżerów oraz zarząd w celu osiągnięcia korzyści ekonomicznych w postaci wyższego zysku. Budżetowanie wspomaga podejmowanie właściwych decyzji. W analizowanym przedsiębiorstwie przygotowywanie planów rzeczowo-finansowych jest elementem obligatoryjnym. Organy nadrzędne wymagają od zarządu spółki opracowania stosownego dokumentu w tym zakresie. W sytuacji kiedy przedsiębiorstwo posiada długoterminowe umowy, realizuje wieloletnie kontrakty pozwala to na precyzyjne zaplanowanie portfela produkcyjnego, prognozowanie kosztów i realizowanie zamówień w odpowiednim harmonogramie.

\section{Literatura}

Controlling funkcyjny w przedsiębiorstwie (2004), red. M. Sierpińska, Oficyna Ekonomiczna, Kraków.

Czubakowska K. (2004), Budżetowanie w controllingu, ODDK, Gdańsk.

Dura A. (2001), Budżetowanie a strategia rynkowa przedsiębiorstwa (w:) Budżetowanie działalności jednostek gospodarczych - teoria i praktyka, red. W. Krawczyk, Akademia Górniczo-Hutnicza w Krakowie, Kraków.

Famielec J. (2012), Ekonomia przemystowa i kierunki jej rozwoju (w:) Ekonomia przemysłowa w warunkach kryzysu finansowego, red. P.P. Małecki, Fundacja Uniwersytetu Ekonomicznego w Krakowie w Krakowie, Kraków.

Famielec J. (2016), Zarys modelu oceny finansowej przedsiębiorstwa w Praktyka działania przedsiębiorstw, ,Ekonomika i Organizacja Przedsiębiorstwa”, nr 2.

Godziszewski B. (2011), Przedsiębiorstwo: teoria i praktyka zarzqdzania, PWE, Warszawa. Jarugowa A., Malec W., Sawicki K. (1990), Rachunek kosztów, PWE, Warszawa.

Komorowski J. (1997), Budżetowanie jako metoda zarzqdzania przedsiębiorstwem, Wydawnictwo Naukowe PWN, Warszawa.

Nowak E. (2003), Rachunkowość zarzq̨dcza, Wydawnictwo Profesjonalnej Szkoły Biznesu, Kraków.

Nowak E. (2014), Analiza sprawozdań finansowych, PWE Warszawa.

Pasternak K. (2005), Zarys zarzqdzania produkcjq, PWE, Warszawa.

Podstawy nauki o przedsiębiorstwie (2007), red. J. Lichtarski, Wydawnictwo Akademii Ekonomicznej we Wrocławiu, Wrocław.

Rachunkowość przedsiębiorstw wybranych sektorów gospodarki (2014), red. T. Kiziukiewicz, PWE, Warszawa.

Rozporządzenie Rady Ministrów z 4 października 2010 r. w sprawie wykazu przedsiębiorców o szczególnym znaczeniu gospodarczo-obronnym, Dz.U. nr 214, poz. 157.

Szczypa P. (2008), Rachunkowość zarzqdcza, CeDeWu.pl, Warszawa.

Ustawa z dnia 29 września 1994 r. o rachunkowości, t.j., Dz.U. 2013, poz. 330, z późn. zm.

Ustawa z dnia 30 sierpnia 1996 r. o komercjalizacji i prywatyzacji przedsiębiorstw państwowych, Dz.U. nr 118, poz. 561, z późn. zm.

Ustawa z dnia 15 września 2000 r. Kodeks spółek handlowych, Dz.U. nr 94, poz. 1037, $\mathrm{z}$ późn. $\mathrm{zm}$.

Ustawa z dnia 2 lipca 2004 r. o swobodzie działalności gospodarczej, Dz.U. nr 173, poz. 1807 , z późn. zm. 
Walczak M., Kowalczyk K. (2010), Rachunkowość i budżetowanie w zarzq̨dzaniu finansami gminy, Difin, Warszawa.

Wnuk-Pel T. (2009), Budżetowanie kosztów, przychodów i wyników (w:) Rachunek kosztów. Podejście operacyjne i strategiczne, red. I. Sobańska, Wydawnictwo C.H. Beck, Warszawa.

\section{Budgeting as an Element of Planning in an Enterprise}

\section{(Abstract)}

The study presents principles of material and financial planning in a production company. An important aspect of managing a business is budgeting, which involves a set of activities performed in accordance with the rules and methods relevant to this process. Activities also mean the quantification of descriptive intentions and the means of their implementation. In addition to asserting that planning and controlling business activities on a budget basis is a must and one of the key elements of sound management, material and financial plans make it possible for a business to describe and plan its needs in a timely and transparent manner for the coming period, and to compare and summarise their costs. The article analyses practices that have been used in budgeting, designing pro-forma accounts related to the implementation of financing processes in companies' day-to-day operations and strategic financial decisions.

Keywords: enterprise, finances, budgeting, financial indicators, defense. 